DOI: $10.19195 / 0524-4544.322 .4$

\author{
PAWEŁ MAJCZAK \\ Uniwersytet Wrocławski \\ e-mail: pawel.majczak@gmail.com
}

\title{
Dyrektywa jako podstawa prawna decyzji administracyjnej
}

\section{Wstęp}

W polskim systemie prawa administracyjnego nie sposób odnaleźć pełnej definicji legalnej decyzji administracyjnej ${ }^{1}$. Jedynie kodeks postępowania administracyjnego $^{2}$ (dalej: k.p.a.) oraz ordynacja podatkowa ${ }^{3}$ (dalej: o.p.) regulują to pojęcie w znaczeniu procesowym. Zgodnie z brzmieniem art. $104 \S 1$ k.p.a. należy stwierdzić, że decyzja administracyjna postrzegana jest jako forma załatwienia sprawy. Decyzje klasyfikuje się na podstawie art. $104 \S 2$ k.p.a. na merytoryczne, rozstrzygające sprawę co do istoty w całości lub w części poprzez przyznanie prawa lub nałożenie obowiązku, oraz niemerytoryczne, które w inny sposób kończą sprawę w danej instancji. Podejmując próbę zdefiniowania pojęcia decyzji administracyjnej, należy zwrócić uwagę na jej cechy charakterystyczne. Zgodnie z definicją zaproponowaną przez B. Adamiak:

Decyzja administracyjna jest to oświadczenie woli kompetentnego organu administracyjnego, podjęte $\mathrm{w}$ wyniku zastosowania normy materialnego prawa administracyjnego lub $\mathrm{w}$ określonym zakresie normy prawa procesowego do ustalonego stanu faktycznego, w trybie, formie, strukturze uregulowanej prawem procesowym, zakomunikowany stronie, w celu wywołania skutku prawnego w sferze

${ }^{1}$ Próbę ujednolicenia rozumienia określenia „decyzja administracyjna” podjęto poprzez chęć wprowadzenia do obrotu prawnego definicji legalnej, którą odnaleźć można w art. 5 ust. 1 pkt 1 projektu ustawy - Przepisy ogólne prawa administracyjnego.

${ }^{2}$ Ustawa z dnia 14 czerwca 1960 r. - Kodeks postępowania administracyjnego (tekst jedn. Dz.U. z 2016 r. poz. 23).

${ }^{3}$ Ustawa z dnia 29 sierpnia 1997 r. — Ordynacja podatkowa (tekst jedn. Dz.U. z 2017 r. poz. 201). 
stosunku materialnoprawnego (decyzja rozstrzygająca sprawę co do jej istoty w całości albo w części) bądź w sferze stosunku procesowego (decyzja w inny sposób kończąca sprawę w danej instancji) ${ }^{4}$.

Minimalne wymagania co do poprawnej formy decyzji administracyjnej zawarte są w art. $107 \S 1$ k.p.a. Kolejna jednostka redakcyjna wskazuje na możliwość wprowadzenia innych składników treści decyzji. Jednym z elementów decyzji administracyjnej jest podstawa prawna. Mogą ją stanowić jedynie przepisy prawa powszechnie obowiązującego, do których Konstytucja $\mathrm{RP}^{5}$ zalicza konstytucję, ustawy, ratyfikowane umowy międzynarodowe, rozporządzenia, akty prawa miejscowego oraz wyjątkowo rozporządzenia prezydenta z mocą ustawy $\mathrm{w}$ trakcie stanu wojennego. A contrario akty administracyjne wewnętrzne podstawy decyzji administracyjnej stanowić nie mogą. Mogą być natomiast pomocne przy uzasadnianiu stanowiska organu. Istotnym zagadnieniem związanym z podstawą prawną decyzji administracyjnej jest prawo zakładowe, do którego można zaliczyć np. statuty jako akty prawa wewnętrznego. Należy jednak pamiętać, że statut nie może stanowić samoistnej podstawy prawnej decyzji administracyjnej, bo ta zawarta jest co do zasady w ustawie ${ }^{6}$.

Wraz z przystąpieniem do Unii Europejskiej Polska przekazała na jej rzecz część suwerennych praw ${ }^{7}$. Co więcej, 1 maja 2004 r. zapewniono prawu Unii Europejskiej pierwszeństwo stosowania przed prawem krajowym, włączając jednocześnie całe prawo pierwotne i wtórne, także to powstałe przed datą przystąpienia do tej organizacji ponadnarodowej. Do form aktów prawnych Unii Europejskiej o mocy wiążącej, wynikających z traktatów zalicza się: rozporządzenia, dyrektywy i decyzje.

\section{Prawo Unii Europejskiej w polskim systemie prawnym}

Konstytucja RP była tworzona w czasie, kiedy cel Polski nakierowany na członkostwo w Unii Europejskiej był jednoznacznie określony i realizowany w praktyce. Aby go urzeczywistnić, ustawodawca zdecydował się na wprowadzenie wielu rozwiązań prawnych poprzedzających przystąpienie naszego kraju

4 B. Adamiak, Wadliwość decyzji administracyjnej, Wrocław 1986, s. 22-23.

5 Konstytucja Rzeczypospolitej Polskiej z dnia 2 kwietnia 1997 r. (Dz.U. Nr 78, poz. 483 ze $\mathrm{zm}$.)

6 Zob. P. Majczak, Podstawa prawna decyzji administracyjnej, „Ius Novum” 2016, nr 4, s. $377-379$.

7 Od wejścia w życie traktatu z Lizbony (1 grudnia 2009 r.) Unia Europejska zastąpiła Wspólnotę Europejską i stała się jej następcą prawnym (art. 1 Traktatu o Unii Europejskiej — dalej: TUE). Stąd po tej dacie mówi się o prawie unijnym a nie wspólnotowym. 
do Unii, aby prawo krajowe było dostosowane w przyszłości do norm unijnych. Mowa przede wszystkim o art. 9, art. 90 i art. 91 konstytucji. Odnoszą się one odpowiednio do związania RP prawem międzynarodowym, wyrażania zgody na związanie umową międzynarodową, na mocy której Polska przekaże organizacji międzynarodowej lub organowi międzynarodowemu kompetencje organów państwowych $\mathrm{w}$ niektórych sprawach, oraz relacji między prawem krajowym a prawem międzynarodowym. Prezydent RP 23 lipca 2003 r. ratyfikował traktat o przystąpieniu do Unii Europejskiej, który wszedł w życie 1 maja $2004 \mathrm{r}^{8}$. Od tego momentu Rzeczpospolita Polska zobowiązała się do przestrzegania prawa unijnego. Należy zwrócić uwagę na odmienności między systemem prawa obowiązującego w Polsce a prawem Unii Europejskiej. System prawa krajowego opiera się na normach prawa stanowionego. Warto odnotować rozwój tzw. prawa sędziowskiego. W polskim prawie nie ma precedensów, jednak można zauważyć rosnący wpływ orzeczeń sądowych na kolejne rozstrzygnięcia sądów i decyzje organów administracji publicznej. Normatywną podstawą dla prawa sędziowskiego jest np. art. $145 \mathrm{a} \S 1$ p.p.s.a. ${ }^{9} \mathrm{w}$ brzmieniu: „, sąd zobowiązuje organ do wydania w określonym terminie decyzji lub postanowienia, wskazując sposób załatwienia sprawy lub jej rozstrzygnięcie, chyba że rozstrzygnięcie pozostawiono uznaniu organu" 10 . W prawie Unii Europejskiej do ustalenia treści normy prawnej niejednokrotnie nie wystarczy odczytanie literalnego brzmienia przepisu prawnego, często cechującego się wysokim stopniem ogólności. Niezbędne staje się odwołanie do tzw. prawa niepisanego, czyli zasad ogólnych prawa Unii Europejskiej. Prawo pisane, zasady ogólne oraz orzecznictwo TSUE składają się na tzw. acquis, czyli dorobek prawny wiążący państwa i ich organy.

Orzekanie na podstawie zasad ogólnych wywodzi się z fragmentu treści art. 19 TUE w brzmieniu: „zapewnia on [TSUE — przyp. autora] poszanowanie prawa w wykładni i stosowaniu Traktatów". Powyższe twierdzenie zostało wysunięte w orzeczeniu Trybunału wydanym na skutek wniesienia pytania prejudycjalnego w sprawach C-6/90 i C-9/90 Francovich i inni ${ }^{11}$. Pytanie sądu państwa członkowskiego dotyczyło zasady i zakresu odpowiedzialności państwa za szkody spowodowane naruszeniem zobowiązań ciążących na nim na mocy prawa unijnego (niedokonaniem transpozycji dyrektywy). W prawie pisanym UE nie było przepisów

8 J. Barcz, M. Górka, A. Wyrozumska, Instytucje i prawo Unii Europejskiej. Podręcznik dla kierunków prawa, zarządzania i administracji, Warszawa 2015, s. 439-440.

9 Ustawa z dnia 30 sierpnia 2002 r. — Prawo o postępowaniu przed sądami administracyjnymi (tekst jedn. Dz.U. z 2016 r. poz. 718 ze zm.)

10 Zob. Przewodnik po prawie administracyjnym, red. W. Jakimowicz, Warszawa 2016, s. 194 195.

11 Wyrok Trybunału z dnia 13 stycznia 2004 r. w sprawach połączonych C-6/90 i C-9/90 Andrea Francovich v. Republika Wtoska, Danila Bonifaci i in. v. Republika Włoska, curia.europa. eu (dostęp: 30.11.2016). 
regulujących to zagadnienie. Trybunał zważył, że unijny porządek prawny może być źródłem uprawnień dla jednostek, przy czym uprawnienia te nie muszą być nadane wprost w traktacie, „lecz powstają one również jako skutek zobowiązań, które traktat nakłada w sposób ściśle określony zarówno na jednostki, jak i na państwa członkowskie oraz instytucje wspólnotowe". Należy nadmienić, że Trybunał nie tworzy nowych zasad, a jedynie odkrywa wspólne zasady wynikające z traktatów, tradycji prawnej państw członkowskich oraz prawa międzynarodowego.

Relewantna z punktu widzenia stosowania prawa unijnego przez organy krajowe jest odpowiedź na pytanie o moc wiążącą orzeczeń TSUE. Przyjmuje się, że w stosunkach wewnętrznych wertykalnych między sądami stricte unijnymi zasadniczo nie sposób wyprowadzić reguły związania sądowym precedensem. Wyjątkiem od powyższej normy jest treść art. 61 Statutu TSUE ${ }^{12}$ w brzmieniu: „Gdy sprawa zostanie skierowana do ponownego rozpoznania przez Sąd, jest on związany orzeczeniem Trybunału Sprawiedliwości co do kwestii prawnych". W stosunkach wewnętrznych horyzontalnych przedstawiona wyżej reguła nie ma wyjątku. W praktyce jednak sądy powołują się na inne orzeczenia oraz wyrażone w nich poglądy, dążąc do zachowania jednolitej linii orzeczniczej. Gdy idzie o moc wiążącą orzeczeń TSUE w stosunku do sądów i organów krajowych, należy bez wątpienia stwierdzić, że orzeczenie wydane na skutek wniesienia pytania prejudycjalnego przez sąd krajowy do TSUE ma w danej sprawie moc wiążącą. Przyjmuje się też, że orzeczenia takie wiążą sądy i organy krajowe wszystkich państw członkowskich $\mathrm{w}$ innych sprawach. Jeżeli sąd krajowy nie zgadzałby się jednak ze stanowiskiem sądu unijnego, powinien zwrócić się z kolejnym pytaniem prejudycjalnym do Trybunału Sprawiedliwości. Niezmiernie istotne, zwłaszcza z punktu widzenia rozpatrywania prawa unijnego jako podstawy prawnej decyzji administracyjnej, jest przyznanie wyłącznej kompetencji do orzekania o nieważności aktów prawa unijnego Trybunałowi Sprawiedliwości Unii Europejskiej (art. 264 TFUE $^{13}$ ). Stąd sędziom sądów krajowych nie wolno, nawet na potrzeby konkretnej sprawy, orzekać o nieważności aktu unijnego. Nie sposób nie wspomnieć o deklaratoryjnym charakterze orzeczeń TSUE ${ }^{14}$. Oznacza to, że zasadniczo działają one wstecz, od momentu nabrania mocy obowiązującej aktu. Wyjątkowo TSUE zastrzega, że dane orzeczenia będą miały zastosowanie na przyszłość oraz do powództw, które zostały już w sądach krajowych wytoczone ${ }^{15}$. W świetle krajo-

12 Protokół Nr 3 w sprawie Statutu Trybunału Sprawiedliwości Unii Europejskiej (Dz.U. UE C 83/210).

13 Traktat o funkcjonowaniu Unii Europejskiej (Dz.U. UE C 83/01).

14 M. Koszowski, Granice związania orzecznictwem Trybunału Sprawiedliwości Unii Europejskiej, [w:] Granice państwa jako granice jurysdykcji w Unii Europejskiej, red. S.M. Grochalski, Dąbrowa Górnicza 2012, s. 35-54.

15 Zob. wyrok Trybunału z dnia 13 stycznia 2004 r. w sprawie C-453/00 Kühne \& Heitz NV v. Produktschap voor Pluimvee en Eieren, Legalis nr 67260. 
wej procedury sądowoadministracyjnej ustawodawca wprowadził przepis art. 272 $\S 3$ p.p.s.a. Umożliwia on wznowienie postępowania sądowoadministracyjnego, gdy taka potrzeba wynika z rozstrzygnięcia organu międzynarodowego działającego na podstawie umowy międzynarodowej ratyfikowanej przez Rzeczpospolitą Polską. Warto się zastanowić, czy istnieje możliwość wznowienia postępowania administracyjnego na skutek orzeczenia TSUE. Ustawa z dnia 29 sierpnia 1997 r. - Ordynacja podatkowa stanowi expressis verbis, że „W sprawie zakończonej decyzją ostateczną wznawia się postępowanie, jeżeli orzeczenie Trybunału Sprawiedliwości Unii Europejskiej ma wpływ na treść wydanej decyzji” (art. $240 § 1$ pkt 11 o.p.) Kodeks postępowania administracyjnego nie zawiera analogicznego uregulowania. Wprawdzie istnieje możliwość żądania wznowienia postępowania na skutek niezgodności aktu normatywnego z umową międzynarodową, jednak tylko wtedy gdy o tej niezgodności orzekł Trybunał Konstytucyjny ${ }^{16}$. Artykuł 145b k.p.a. stanowi, że: „Można żądać wznowienia postępowania również w przypad$\mathrm{ku}$, gdy zostało wydane orzeczenie sądu stwierdzające naruszenie zasady równego traktowania". Pojęcie sądu należy rozumieć szeroko, zarówno jako sąd krajowy, jak i np. Trybunał Sprawiedliwości Unii Europejskiej czy Europejski Trybunał Praw Człowieka ${ }^{17}$. W tej przesłance mieści się jednak tylko wąska grupa orzeczeń. Trudno zgodzić się ze stanowiskiem M.P. Kaszubskiego: „Jeżeli przyjąć, że »właściwym sądem« przewidzianym do rozstrzygnięcia kwestii wstępnej jest sąd wspólnotowy, nic nie stoi na przeszkodzie wznowieniu postępowania na podstawie wyżej wymienionego artykułu" (art. $145 \S 1$ pkt 7 k.p.a.) ${ }^{18}$. Należy wyjaśnić, że gdy rozpatrzenie sprawy i wydanie decyzji zależy od uprzedniego rozstrzygnięcia zagadnienia wstępnego przez inny organ lub sąd, organ administracji publicznej zobligowany jest zawiesić postępowanie i w zależności od sytuacji wystąpić do właściwego podmiotu o rozstrzygnięcie albo wezwać stronę, aby sama tego dokonała. W nadzwyczajnych sytuacjach organ może rozstrzygnąć zagadnienie wstępne we własnym zakresie (art. 100 k.p.a.). Treścią zagadnienia wstępnego może być: „wypowiedź co do uprawnienia lub obowiązku, stosunku lub zdarzenia prawnego albo innych jeszcze okoliczności mających znaczenie prawne"19. Gdyby uznać orzeczenia TSUE za zagadnienia wstępne, konieczne byłoby zawieszanie każdego

16 Zob. B. Adamiak, Zgodność aktu normatywnego z Konstytucja, umowa międzynarodowa lub ustawa - jako przestanka prawidłowości decyzji administracyjnej, „Przegląd Sądowy” 2007, nr 1, s. 3-15.

17 A. Wróbel, M. Jaśkowska, Kodeks postępowania administracyjnego. Komentarz, Warszawa 2016, s. 793.

18 M.P. Kaszubski, Możliwość wznowienia postepowania administracyjnego z uwagi na późniejsze orzeczenie Trybunału Sprawiedliwości - w świetle sprawy Kühne, „Kwartalnik Prawa Publicznego" 2004, nr 2, s. 291.

19 B. Graczyk, O niektórych zagadnieniach prejudycjalności w orzecznictwie administracyjnym, „Zeszyty Naukowe Uniwersytetu Łódzkiego. Prawo” 1965, nr 38, s. 91-92. 
postępowania administracyjnego i występowanie do TSUE o rozstrzygnięcie kwestii wpadkowej, co jest nieracjonalne i do czego organ administracji publicznej nie ma uprawnień, nawet jeżeli miałby wystąpić z pytaniem prejudycjalnym do TSUE. Rozpatrując materię uchylenia decyzji, nie należy zapominać o art. 154 k.p.a. traktującym o zmianie lub uchyleniu decyzji ostatecznej, na podstawie której żadna ze stron nie nabyła prawa, oraz art. 155 k.p.a. będącym podstawą do zmiany lub uchylenia decyzji ostatecznej, na mocy której strona nabyła prawo ${ }^{20}$. Przyjmuje się, że gdy kodeks postępowania administracyjnego nie daje podstaw do zmiany lub uchylenia decyzji w trybie wznowienia postępowania (art. $145 \S 1$ k.p.a.) lub stwierdzenia nieważności (art. 156 § 1 k.p.a.), można stosować w takich sytuacjach art. 154 i art. 155 k.p.a ${ }^{21}$. Jednakże tutaj również występują ograniczenia co do rodzajów decyzji, które mogą zostać poddane weryfikacji, ponieważ w trybie art. 154 k.p.a. lub art. 155 k.p.a. mogą być uchylane lub zmieniane jedynie decyzje ostateczne, konstytutywne oraz mające charakter uznaniowy ${ }^{22}$. Można spotkać się ze stanowiskiem, zgodnie z którym w tych trybach mogą być zmieniane lub uchylane nie tylko decyzje konstytutywne, lecz także deklaratoryjne, stwierdzające nabycie przez stronę praw z mocy ustawy ${ }^{23}$. Do uchylenia lub zmiany decyzji w trybie art. 154 i art. 155 k.p.a. wymagane jest, aby przemawiały za tym interes społeczny lub słuszny interes strony, którym odpowiada niewątpliwie zapewnienie poszanowania prawa unijnego. Jeżeli strona nie nabyła praw z decyzji, to organ, który wydał akt, może go w każdej chwili uchylić lub zmienić. Jeśli prawa zostały nabyte w wyniku wydania decyzji, konieczne jest wyrażenie przez stronę zgody na uchylenie lub zmianę decyzji oraz brak przepisu szczególnego sprzeciwiającego się temu zabiegowi. Należy zauważyć, że skoro podstawową przesłanką zmiany lub uchylenia decyzji w trybie art. 155 k.p.a. jest zgoda strony, tryb ten należy ocenić jako mało przydatny w sytuacji gdy ostateczna decyzja, niezgodna z prawem unijnym, jest dla strony korzystna. W razie niewyrażenia przez stronę zgody na uchylenie lub zmianę decyzji w trybie art. 155 k.p.a. istnieje jeszcze możliwość skorzystania z art. $161 \S 1$ k.p.a. Należy zaznaczyć, że tryb ten może być zastosowany dopiero wtedy, gdy w inny sposób nie można usunąć stanu zagrażającego życiu lub zdrowiu ludzkiemu albo zapobiec poważnym szkodom dla gospodarki narodowej, lub dla ważnych interesów państwa. Zbigniew Kmieciak wysunął pogląd, zgodnie z którym skorzystanie z tego środka stanowiłoby przejaw prounijnej wykładni prawa krajowego ${ }^{24}$. Taka interpretacja może wydawać się daleko idąca,

20 Wyrok SN z dnia 6 stycznia 1999 r., III RN 101/98, LEX nr 37676.

21 Zob. Kodeks postępowania administracyjnego. Komentarz dla praktyków, red. L. KlatWertelecka, A. Mudrecki, Gdańsk 2012, s. 639-647.

22 Wyrok NSA w Warszawie z dnia 21 kwietnia 2006 r., II OSK 770/05, LEX nr 211853.

23 Wyrok NSA w Warszawie z dnia 17 stycznia 1996 r., III SA 892/95, LEX nr 24009.

${ }^{24}$ Z. Kmieciak, Wzruszalność ostatecznych (prawomocnych) rozstrzygnięć organów krajowych niezgodnych z unijnym porzadkiem prawnym i porzadkiem konwencyjnym, [w:] System Prawa Administracyjnego, red. R. Hauser, Z. Niewiadomski, A. Wróbel, t. 3, Warszawa 2014, s. 228. 
lecz wszelkie oceny muszą uwzględniać okoliczności konkretnej sprawy, zatem nie można możliwości skorzystania z trybu art. 161 k.p.a. absolutnie wyłączać.

$\mathrm{Na}$ prawo pisane Unii Europejskiej składają się: prawo pierwotne, umowy międzynarodowe Unii, prawo pochodne oraz akty Wspólnej Polityki Zagranicznej i Bezpieczeństwa. Prawo pierwotne to traktaty (obecnie TUE i TFUE), akty Rady lub Rady Europejskiej o charakterze konstytucyjnym a także ogólne zasady prawa zapisane $\mathrm{w}$ traktatach. Należy zaznaczyć, że od wejścia w życie traktatu z Lizbony moc równą traktatom zyskała Karta Praw Podstawowych (art. 6 TUE). Umowy międzynarodowe zawierane przez Unię z państwami trzecimi należy traktować jako akty prawa międzynarodowego. Trzeba zaznaczyć, że w odniesieniu do państw członkowskich i instytucji unijnych mają one wiążący charakter (art. 216 ust. 2 TFUE). Na prawo pochodne składają się akty ustawodawcze (art. 289 ust. 3 TFUE), akty nieustawodawcze oraz inne akty. Akty ustawodawcze to rozporządzenia, dyrektywy i decyzje. Posiadają one charakter wiążący, określają istotne elementy danej dziedziny i przyjmowane są w drodze zwykłej (art. 294 TFUE) lub specjalnej (art. 289 ust. 2 TFUE) procedury ustawodawczej. Wydawane są przez Parlament Europejski lub Radę. Akty nieustawodawcze to także rozporządzenia, dyrektywy i decyzje. Mają one moc wiążącą. W odróżnieniu od aktów ustawodawczych nie są przyjmowane $\mathrm{w}$ drodze zwykłej lub specjalnej procedury ustawodawczej. Pochodzą one od Komisji lub Rady. Decyzje Rady przyjęte na podstawie art. 24 i art. 26 TUE także zaliczane są do aktów nieustawodawczych. Należą do nich również tzw. akty delegowane (art. 290 TFUE) oraz akty wykonawcze (art. 291 TFUE). Ważne jest, że w wypadku tych ostatnich kompetencje wykonawcze wobec prawa UE spoczywają na państwach członkowskich (art. 291 ust. 1 TFUE). Pod pojęciem innych aktów należy rozumieć przede wszystkim zalecenia i opinie, które zgodnie z art. 288 akapit 5 TFUE nie mają mocy wiążącej ${ }^{25}$.

Traktatowa regulacja odnosząca się do źródeł prawa Unii Europejskiej znajduje się w art. 288 TFUE. Zgodnie z nim: „Rozporządzenie ma zasięg ogólny. Wiąże w całości i jest bezpośrednio stosowane we wszystkich Państwach Członkowskich”. Dyrektywa natomiast: „wiąże każde Państwo Członkowskie, do którego jest kierowana, w odniesieniu do rezultatu, który ma być osiągnięty, pozostawia jednak organom krajowym swobodę wyboru formy i środków”. „Decyzja wiąże w całości. Decyzja, która wskazuje adresatów, wiąże tylko tych adresatów". Trudno uznać, aby powyższe unormowanie kompleksowo regulowało materię źródeł prawa unijnego. Stąd, na potrzeby niniejszego opracowania, warto krótko scharakteryzować cechy dyrektyw.

Po pierwsze, dyrektywa wiąże każde państwo członkowskie, do którego jest kierowana. Państwo zobligowane jest do jej wdrożenia. Musi ją zatem nie tylko transponować, lecz także implementować, czyli zapewnić rezultat przewidziany

25 J. Barcz, M. Górka, A. Wyrozumska, Instytucje i prawo Unii Europejskiej. Podręcznik dla kierunków zarządzania i administracji, Warszawa 2011, s. 267-305. 
w dyrektywie. Implementację dyrektywy ocenia się przez pryzmat całości działania państwa, na które składa się m.in. praktyka ustawodawcza, administracyjna i sądowa. Implementacja trwa przez cały okres obowiązywania dyrektywy. Pod pojęciem transpozycji rozumie się proces tworzenia przepisów prawa krajowego powszechnie obowiązujących. Należy zwrócić uwagę, że zadaniem państwa jest stworzenie przepisów, a nie ich przekopiowanie z dyrektywy. Nie można też nadać dyrektywie mocy bezpośrednio obowiązującej. Po drugie, adresatem dyrektywy jest każde państwo członkowskie Unii Europejskiej a nie jego poszczególne organy lub instytucje. Oznacza to, że organ właściwy do ustanowienia przepisów wykonujących dyrektywę będzie ustalony na podstawie wewnętrznego porządku krajowego. Po trzecie, dyrektywa wiąże prawnie państwa członkowskie co do określonego w niej rezultatu oraz wyznaczonego w dyrektywie terminu jej wykonania. Po czwarte, władzom krajowym pozostawiono wybór metod i form wdrożenia dyrektywy. Najważniejsze jest osiągnięcie rezultatu przewidzianego $\mathrm{w}$ dyrektywie, niezależnie od tego, czy władze będą działać w formach cywilnoprawnych, czy administracyjnoprawnych. Dyrektywa nie musi być transponowana w formie ustawy. Jeśli będzie zawierała rozwiązania szczegółowe, które np. w Polsce stanowią materię rozporządzeń, w takiej właśnie formie można ją wdrożyć do porządku krajowego. Nie jest konieczne również uchwalenie nowego aktu prawnego. Jeśli jest to możliwe, wystarczy np. znowelizować dotychczasowe przepisy. Państwa członkowskie mają obowiązek poinformować Komisję Europejską o sposobie wdrożenia dyrektywy ${ }^{26}$.

Gdy dyrektywa nie zostanie implementowana lub implementacja przebiegnie w sposób nieprawidłowy, punktem odniesienia dla organów stosujących prawo stają się postanowienia dyrektywy. Zachodzi konieczność ustalenia zgodności norm prawa krajowego z dyrektywą. Jeśli norma prawa krajowego okaże się sprzeczna z postanowieniami dyrektywy, uzasadniona będzie odmowa zastosowania tej pierwszej, jeżeli norma unijna będzie spełniała kryteria bezpośredniego stosowania, tzn. będzie jasna i precyzyjna, bezwarunkowa oraz zupełna. Nie budzi wątpliwości, że jednostka może się na taką dyrektywę skutecznie powoływać przed sądem krajowym, który jest zobowiązany uwzględnić prawo unijne w toku orzekania ${ }^{27}$. Gdy sąd krajowy uzna, że ma wątpliwości co do wykładni traktatów lub ważności aktów przyjętych przez instytucje, organy lub jednostki organizacyjne Unii, może on zwrócić się do Trybunału Sprawiedliwości z pytaniem prejudycjalnym (art. 267 TFUE). Organ administracji publicznej z takiej możliwości skorzystać nie może ${ }^{28}$. W tym miejscu rodzi się ważkie pytanie, czy obowiązek

26 Stosowanie prawa Unii Europejskiej przez sądy, red. A. Wróbel, Warszawa 2010, s. 67-72.

27 M. Zapała, Stosowanie dyrektyw wspólnotowych przez organy administracyjne, „Państwo i Prawo" 2005, z. 11, s. 90-96.

28 Termin „sąd” w rozumieniu art. 267 TFUE jest pojęciem autonomicznym. Przejawia się to w różnym rozumieniu tych samych określeń na gruncie prawa krajowego i unijnego. Konieczne jest, aby instytucja sądowa spełniała łącznie następujące warunki: działała na podstawie ustawy, orzekała na podstawie prawa, działała na podstawie procedur określonych w prawie wewnętrznym, rozstrzygała spory między stronami, wydawała orzeczenia wiążące dla stron, a także była nieza- 
uwzględniania prawa unijnego w postępowaniu spoczywa również na organach administracji publicznej? Pomocne w udzieleniu na nie odpowiedzi z pewnością okaże się orzecznictwo, w którym stwierdzono, że jeżeli spełnione są warunki bezpośredniego stosowania normy unijnej, to: ,wszystkie organy administracji, włącznie z władzami zdecentralizowanymi, takimi jak gminy, są zobowiązane do stosowania takich przepisów" 29 . Sądy krajowe wysunęły podobny pogląd, stwierdzając, że: „Urzędnik administracyjny, funkcjonariusz aparatu państwowego lub sędzia nie może zamykać oczu na przepisy międzynarodowe i nie uwzględniać ich w swej działalności oficjalnej”30. Wątpliwości nie budzi zatem, że organy administracji publicznej są zobowiązane do stosowania prawa UE w konkretnej sprawie. Problem pojawia się, gdy prawo krajowe jest niezgodne z prawem unijnym. Rodzi się pytanie, czy organ może pominąć niezgodną z prawem UE normę krajową. Organ, odmawiając zastosowania sprzecznej z prawem unijnym normy krajowej, wprawdzie zachowa się zgodnie z oczekiwaniami UE, jednak z drugiej strony istnieje ryzyko pogwałcenia normy obowiązującego prawa krajowego. Zastosowanie zasady pierwszeństwa i bezpośredniego skutku przez organ administracji publicznej często stoi w sprzeczności do zasady podziału władzy. Organ nie tylko wkraczałby w kompetencje władzy prawodawczej, lecz także podważał akty wykonawcze wydawane przez organy krajowe (np. rozporządzenia poszczególnych ministrów). Należy mieć również na uwadze ograniczenia wynikające z podległości organom nadrzędnym oraz sądową kontrolę rozstrzygnięć administracji ${ }^{31}$. Wprawdzie NSA stwierdził, że urzędnik administracyjny nie może zamykać oczu na przepisy międzynarodowe, jednak nie wyartykułował wprost, że w razie sprzeczności organ ma nie stosować normy prawa krajowego. Stąd organy krajowe, dążąc do jak najpełniejszego wykonania dyspozycji płynących z prawa UE, powinny korzystać z dobrodziejstwa prounijnej wykładni, przejawiającej się w interpretowaniu prawa krajowego w sposób najbardziej zgodny z celem i treścią prawa unijnego, przy użyciu wszelkich uznanych w porządku krajowym metod wykładni. Należy zaznaczyć, że chodzi o całe prawo krajowe, a nie tylko służące implementacji normy unijnej. Wykładnia zgodna sprawdza się w obszarach, w których normy krajowe pozostawiają luz interpretacyjny. Nie może jednak prowadzić do wykładni prawa krajowego contra legem ${ }^{32}$. Poza tym należy rozróżnić dwie odmienne sytuacje. Pierwsza zachodzi wówczas gdy istnieje orzecznictwo Trybunału bądź innych sądów w podobnych sprawach, gdy są one oczywiste. Organ administracji publicz-

wisła - System ochrony prawnej Unii Europejskiej, red. A. Wyrozumska, Warszawa 2010, s. 310. Organ administracji publicznej nie jest zatem sądem w rozumieniu art. 267 TFUE.

29 Wyrok TS z dnia 22 czerwca 1989 r. w sprawie 103/88, Fratelli Costanzo SpA przeciwko Comune di Milano, EU:C:1989:256.

30 Wyrok NSA z dnia 5 czerwca 1991 r., II SA 35/91, Legalis nr 36876.

31 N. Półtorak, Ochrona uprawnień wynikających z prawa Unii Europejskiej w postępowaniach krajowych, Warszawa 2010, s. 100-102.

32 J. Barcz, M. Górka, A. Wyrozumska, Instytucje i prawo Unii Europejskiej. Podręcznik dla kierunków prawa, zarządzania i administracji, Warszawa 2015, s. 300-302. 
nej nie powinien mieć wtedy wątpliwości orzeczniczych. Druga — gdy w danej materii nie było dotychczas żadnych przepisów w prawie krajowym, dyrektywa nie została w terminie transponowana, a z przepisów krajowych nie da się wyinterpretować działania zgodnego z założeniami dyrektywy. Rodzi się pytanie, jak powinien $\mathrm{w}$ takiej sytuacji zachować się organ oraz czy procedurę postępowania reguluje prawo Unii Europejskiej, czy prawo krajowe?

Podejmując próbę odpowiedzi na postawione pytanie, należy wyjaśnić pojęcie autonomii proceduralnej, wywodzonej z art. 4 ust. 3 TUE w brzmieniu: „Zgodnie z zasadą lojalnej współpracy Unia i Państwa Członkowskie wzajemnie się szanują i udzielają sobie wzajemnego wsparcia w wykonywaniu zadań wynikających z Traktatów". Powyższa konstrukcja prawna, wypracowywana orzecznictwem TSUE, a następnie konkretyzowana i uzupełniana ustawami oraz rozstrzygnięciami sądów krajowych ${ }^{33}$, ma zastosowanie wyłącznie wówczas, gdy przepisy prawa unijnego wskazują na cel, jaki ma zostać osiągnięty działaniami państw członkowskich, natomiast nie precyzują formy działania organów państwowych. W prawie unijnym nie sposób bowiem odnaleźć systemowej regulacji środków służących dochodzeniu roszczen ${ }^{34}$. Autonomia proceduralna jawi się jako swoboda państw członkowskich „w wyborze i regulacji środków proceduralnych, według których wykonywane mają być w prawie krajowym roszczenia wynikające z prawa unijnego" 35 . Dochodzenie tych roszczeń na drodze sądowej i administracyjnej ma się opierać na przepisach proceduralnych państw członkowskich, takich jak ustawa z dnia 14 czerwca 1960 r. — Kodeks postępowania administracyjnego czy ustawa z dnia 30 sierpnia 2002 r. - Prawo o postępowaniu przed sądami administracyjnymi. Andrzej Wróbel zwrócił uwagę, że istnienie zasady autonomii proceduralnej związane jest $\mathrm{z}$ bezpośrednim skutkiem niektórych norm unijnego prawa materialnego. Jeżeli przepisy prawa UE przyznają jednostkom uprawnienia, obowiązkiem państw członkowskich jest zastosowanie wewnętrznych instytucji prawa proceduralnego, aby zapewnić realizację prawa unijnego ${ }^{36}$. Omawiana zasada powinna być urzeczywistniana głównie w procesie stanowienia prawa, np. w drodze poprawnej implementacji. W praktyce jednak to organy stosujące prawo znają najlepiej konkretne sprawy, którymi się zajmują. $\mathrm{Z}$ tego względu mają możliwość najpełniejszej realizacji dyspozycji wynikających z prawa unijnego ${ }^{37}$.

Tytułem egzemplifikacji należy wskazać na zastosowanie autonomii proceduralnej w praktyce. Akty prawa unijnego niejednokrotnie posługują się pojęciem

33 Z. Kmieciak, op. cit., s. 223.

34 N. Półtorak, op. cit., s. 38.

35 Ibidem, s. 62.

36 A. Wróbel, Autonomia proceduralna, „Ruch Prawniczy, Ekonomiczny i Socjologiczny” 2005, z. 1, s. 36 .

37 M. Domańska, Zasada autonomii proceduralnej państw członkowskich i jej ograniczenia wynikajace z zasady efektywności, [w:] Stosowanie prawa Unii Europejskiej przez sady. Zasadyorzecznictwo - piśmiennictwo, t. 2, red. A. Wróbel, Warszawa 2007, s. 327. 
środków ochrony prawnej, którym należy przypisać znaczenie środków zaskarżenia. Zasadniczo obowiązek zapewnienia takich środków spoczywa na państwach członkowskich UE. Rozwiązanie takie znalazło zastosowanie m.in. w dyrektywie 2004/38 38 , której art. 31 ust. 1 stanowi: „Osoby zainteresowane posiadają możliwość odwołania się na drodze sądowej i, w określonym przypadku, administracyjnej w przyjmującym Państwie Członkowskim, lub domagać się dokonania rewizji każdej decyzji podjętej wobec nich ze względów porządku publicznego, bezpieczeństwa publicznego lub zdrowia publicznego". Polskim aktem implementującym tę dyrektywę jest ustawa z dnia 14 lipca 2006 r. o wjeździe na terytorium Rzeczypospolitej Polskiej, pobycie oraz wyjeździe z tego terytorium obywateli państw członkowskich Unii Europejskiej i członków ich rodzin ${ }^{39}$, która w art. 13 przyznaje kompetencje komendantowi placówki Straży Granicznej do wydania decyzji o odmowie wjazdu na terytorium Rzeczypospolitej Polskiej oraz decyzji o unieważnieniu wizy. Odwołanie od decyzji komendanta placówki Straży Granicznej przysługuje do komendanta Głównego Straży Granicznej. Procedurę odwoławczą określa natomiast kodeks postępowania administracyjnego.

Odnosząc powyższe uwagi do prawa polskiego, warto zastanowić się, jak powinien postąpić organ administracji publicznej, jeżeli uchybiono terminowi transpozycji dyrektywy regulującej materię nieznaną wcześniej polskiemu prawodawcy? Należy rozróżnić dwie sytuacje stosowania dyrektywy unijnej w systemie prawa krajowego. Pierwsza zachodzi wówczas, gdy dyrektywa została uchwalona i opublikowana w Dzienniku Urzędowym UE, ale nie upłynął jeszcze termin jej transpozycji. Wtedy należy stosować prawo krajowe. Jeżeli brakuje przepisów w prawie krajowym, to nie można rozwiązać sprawy, gdyż decyzja administracyjna wydana byłaby wtedy bez podstawy prawnej. Dyrektywa nie może rodzić skutku bezpośredniego przed upływem terminu transpozycji ${ }^{40}$. Należy zaznaczyć, że w świetle zasady lojalnej współpracy po uchwaleniu dyrektywy i jej opublikowaniu w Dzienniku Urzędowym UE państwu nie wolno uchwalać przepisów sprzecznych z dyrektywą, wpływających na działanie organów państwa po upływie terminu transpozycji. Druga sytuacja zachodzi, gdy upłynął termin transpozycji dyrektywy, a państwo pozostaje w zwłoce. Jeżeli dyrektywa spełnia warunki bezpośredniego stosowania, jednakże nie określa formy, w jakiej ma nastąpić przyznanie jednostce uprawnieńn ${ }^{41}$, to zgodnie z zasadą autonomii proceduralnej w wypadku Polski należy stosować przepisy proceduralne wynikające $\mathrm{z}$ k.p.a. oraz przepisy materiale zawarte $\mathrm{w}$ dyrek-

38 Dyrektywa 2004/38/WE Parlamentu Europejskiego i Rady z dnia 29 kwietnia 2004 r. w sprawie prawa obywateli Unii i członków ich rodzin do swobodnego przemieszczania się i pobytu na terytorium Państw Członkowskich, zmieniająca rozporządzenie (EWG) nr 1612/68 i uchylająca dyrektywy 64/221/EWG, 68/360/EWG, 72/194/EWG, 73/148/EWG, 75/34/EWG, 75/35/EWG, 90/364/EWG, 90/365/EWG i 93/96/EWG (Dz.U.UE.L. z 2004 r. Nr 158, s. 77).

39 Tekst jedn. Dz.U. z 2017 r. poz. 900 ze zm.

40 J. Barcz, M. Górka, A. Wyrozumska, Instytucje i prawo Unii Europejskiej. Podręcznik dla kierunków prawa, zarządzania i administracji, Warszawa 2015, s. 295.

${ }^{41}$ Dyrektywa nie może rodzić obowiązków dla jednostek — ibidem, s. 304. 
tywie. Odpowiedź na pytanie, w jakiej formie ma nastąpić konkretyzacja sytuacji prawnej obywatela, jeżeli przepis prawny nie reguluje bezpośrednio jego sytuacji, została udzielona w glosie B. Adamiak i J. Jendrośki. Autorzy zajęli stanowisko opowiadające się za tym, że gdy przepis prawa nie określa formy konkretyzacji, organ powinien dokonać jej w formie decyzji administracyjnej. Trzeba zwrócić uwagę, że domniemać można formę decyzji administracyjnej, a nie jej podstawę prawną. Autorzy uznali ponadto, że czynności materialno-techniczne nie stanowią formy działania, która może wyznaczyć sytuację prawną obywatela. Jak stwierdzili, czynności materialno-techniczne: „mają zastosowanie w zakresie wykonania uprawnień i obowiązków obywatela wypływających bezpośrednio z przepisu prawa bądź z decyzji administracyjnej" "22. Należy zaznaczyć, że gdy organ administracyjny będzie miał podstawy do działania $w$ innych formach, np. przez zawieranie umów cywilnoprawnych, nie będzie wydawał decyzji administracyjnych ${ }^{43}$. Jak pokazuje praktyka, ustawodawca decyduje się niekiedy na konkretyzację praw i obowiązków indywidualnych wskutek dokonania czynności materialno-technicznej ${ }^{44}$, a nie jak postulowali B. Adamiak i J. Jendrośka — decyzji administracyjnej. Często dzieje się tak z powodu chęci przyspieszenia i uproszczenia załatwiania spraw sztampowych, których rezultatem jest przyznanie uprawnień. Rozstrzygnięcia odmowne zasadniczo kończą się wydaniem decyzji administracyjnej, albowiem najpełniej realizuje ona gwarancje procesowe przysługujące jednostce. Tytułem przykładu, wpis do rejestru działalności regulowanej jest czynnością materialno-techniczną (art. 65 ust. 1 u.s.d.g. ${ }^{45}$ ), natomiast odmowa wpisu przedsiębiorcy do tego rejestru następuje w formie decyzji administracyjnej (art. 68 u.s.d.g.). Podobnie ustawienie znaku drogowego ma charakter czynności materialno-technicznej. Odmowa postawienia znaku powinna natomiast nastąić w formie decyzji administracyjnej ${ }^{46}$. Celem poczynionych uwag nie jest wykazanie sprzeczności między poglądami B. Adamiak i J. Jendrośki a praktyką prawodawczą. Należy zwrócić uwagę, że w początkowych latach działalności NSA można było odnotować tendencję do wymagania formy decyzji administracyjnej w szerokim zakresie ze względu na wąską kognicję sądów administracyjnych sprowadzającą się do kontroli decyzji administracyjnych. W obecnym stanie prawnym, gdzie właściwość sądów administracyjnych jest określona szeroko, nie ma takiej potrzeby. Odnosząc powyższe uwagi do zadanego na wstępie pytania, należy uznać, że jeżeli bezpośrednio stosowane przepisy prawa Unii Europejskiej nie wskazywałyby na formę konkretyzacji praw i obowiązków indywidualnych, to właściwe byłoby wydanie decyzji administracyjnej. Relewant-

42 B. Adamiak, J. Jendrośka, Glosa do wyroku NSA z dnia 27 kwietnia 1981 r., SA 767/81, Orzecznictwo Sądów Polskich i Komisji Arbitrażowych OSPiKA 1983, Nr 5, poz. 109.

43 Zob. postanowienie WSA w Gdańsku z dnia 28 czerwca 2005 r., II SA/Gd 188/05, LEX nr 180323.

44 Zob. uchwała NSA w Warszawie z dnia 15 listopada 1999, OPK 24/99, LEX nr 40267.

45 Ustawa z dnia 2 lipca 2004 r. o swobodzie działalności gospodarczej (tekst jedn. Dz.U. z 2016 r. poz. 1829 ze zm.).

46 Wyrok WSA w Warszawie z dnia 2 listopada 2005 r., VI SA/Wa 1515/05, LEX nr 214331. 
ne jest jednak, że z punktu widzenia krajowych organów administracji publicznej, aby mogły one wydać decyzję administracyjną, muszą dysponować podstawą prawną w postaci normy prawa krajowego. Zgodnie z zasadą podziału władzy to na prawodawcy ciąży obowiązek implementowania dyrektywy w należytym terminie. Przyjęcie, że organ krajowy ma domniemywać formę decyzji administracyjnej w przypadku bezpośredniego stosowania normy unijnej dyrektywy jest ryzykowne przede wszystkim ze względu na to, że jeżeli ustawodawca w aktach prawa krajowego, implementujących dyrektywę z opóźnieniem, zdecydowałby się jednak na wprowadzenie formy czynności materialno-technicznej zamiast decyzji administracyjnej, mogłoby dojść do sytuacji, w której takie same sprawy w zależności od momentu rozstrzygnięcia byłyby rozstrzygane w różnych formach. Jedne zakończyłyby się decyzją administracyjną (gdy za podstawę prawną decyzji uchodziłyby bezpośrednio stosowane przepisy prawa unijnego), a dla innych właściwa byłaby forma czynności materialno-technicznej (gdy stosowane byłyby transponujące dyrektywę przepisy krajowe). Takie rozwiązanie byłoby niedopuszczalne choćby ze względu na to, że odmiennie kształtowałoby się prawo do zaskarżenia tych form. Warto się także zastanowić, czy decyzja administracyjna wydana w oparciu o przepisy dyrektywy unijnej nie byłaby dotknięta sankcją nieważności jako wydana bez podstawy prawnej (art. $156 \S 1$ pkt 2 k.p.a.). Celem powyższych rozważań jest m.in. zwrócenie uwagi na problem, jaki niesie za sobą uchybienie przez państwo członkowskie jednemu ze zobowiązań, które ciążą na nim na mocy traktatów, czyli w omawianym przypadku — transpozycji dyrektywy ${ }^{47}$. Można dodatkowo zastanowić się nad właściwością organu. Jeżeli nie dałoby się jej ustalić na podstawie norm dyrektywy, która posługiwałaby się np. pojęciem ,właściwe organy państwowe", trudno wyobrazić sobie możliwość bezpośredniego zastosowania takiej dyrektywy. Wskazane jest zatem przyjęcie rozwiązania, w którym nie będzie można rozstrzygnąć sprawy administracyjnej, dopóki organ administracji publicznej nie będzie dysponował normą prawa krajowego transponującą dyrektywę, a także gdy nie będzie możliwości skorzystania z wykładni prounijnej.

\section{Podsumowanie}

Bezsprzeczne jest, że podstawę prawną decyzji administracyjnej mogą stanowić wyłącznie przepisy prawa powszechnie obowiązującego. Zasadny wydaje się postulat, aby nosiły one rangę ustawy. Niemały wpływ na podstawę prawną decyzji ma także prawo Unii Europejskiej stanowione przede wszystkim w formach rozporządzeń, dyrektyw i decyzji. Dyrektywa wymaga implementacji do systemu krajowego. Jeżeli państwo dokona jej prawidłowego wdrożenia, to podstawą prawną decyzji administracyjnej będą przepisy krajowe, transponujące dyrekty-

47 System ochrony..., s. 93-136. 
wę. Problem pojawia się, gdy państwo uchybi jednemu ze zobowiązań (w tym przypadku wdrożeniu dyrektywy w terminie), które ciążą na nim na mocy traktatów. Należy uznać, że organ administracji publicznej zobowiązany jest uwzględniać przepisy unijne w swej działalności oficjalnej. W sytuacji braku prawidłowej transpozycji winno się orzekać w duchu przepisów prawa unijnego, stosując np. wykładnię zgodną. Jeżeli jednak normy dyrektywy nie spełniają kryteriów bezpośredniego stosowania, to bez wątpienia nie mogą stanowić podstawy prawnej decyzji administracyjnej.

\title{
Directive as the legal basis of the administrative decision
}

\begin{abstract}
Summary
An administrative decision is the goal of the administrative procedure. In accordance with the rule of law's principle expressed in the article 7 of The Constitution of the Republic of Poland: „The organs of public authority have to function on the basis of, and within the limits of the law". This principle, which has been also confirmed in article 6 of Administrative Procedure Code, is inextricably connected with the necessity of the legal basis of the administrative decisions, which may be the only binding universal law provisions. It seems to be reasonable that they have the rank of enactment. Considerable impact on the legal basis for the administrative decision is as well European Union's law. Directive is one of the European Union's secondary law and binds, as to the result to be achieved, upon each Member State to which it is addressed. Directive requires proper implementation to national law's system and native rules, which were a part of its transposition, become legal basis of administrative decision. Problem appears when the Member State breaches the term of the implementation or have the directive inaptly implemented. It is appropriate to assume that as long as the public authority is not disposing national law's norm, which transposes directive and as well as it is not able to use union-friendly interpretation, public authority will not have the competence to adjudicate administrative cases.
\end{abstract}

Keywords: administrative decision, legal base, directive, implementation of European Union's directive, legal sources.

\section{Bibliografia}

Adamiak B., Wadliwość decyzji administracyjnej, Wrocław 1986.

Adamiak B., Zagadnienie domniemania formy decyzji administracyjnej, [w:] Podmioty administracji publicznej i prawne formy ich działania: studia i materiały z Konferencji Naukowej poświęconej jubileuszowi 80-tych urodzin Profesora Eugeniusza Ochendowskiego, Toruń, 15-16 listopada 2005, Toruń 2005.

Adamiak B., Zgodność aktu normatywnego z Konstytucja, umowa międzynarodowa lub ustawajako przesłanka prawidłowości decyzji administracyjnej, PS 2007, nr 1.

Adamiak B., Jendrośka J., Glosa do wyroku NSA z dnia 27 kwietnia 1981 r., SA 767/81, OSPiKA 1983, Nr 5, poz. 109. 
Baran B. et al., Europeizacja prawa administracyjnego, [w:] System Prawa Administracyjnego, t. 3, red. R. Hauser, Z. Niewiadomski, A. Wróbel, Warszawa 2014.

Barcz J., Górka M., Wyrozumska A., Instytucje i prawo Unii Europejskiej. Podręcznik dla kierunków zarzadzania i administracji, Warszawa 2011.

Barcz J., Górka M., Wyrozumska A., Instytucje i prawo Unii Europejskiej. Podręcznik dla kierunków prawa, zarzadzania i administracji, Warszawa 2015.

Biernat S., Wpływ prawa wspólnotowego na wzruszanie ostatecznych decyzji administracyjnych i prawomocnych orzeczeń sądowych w państwach członkowskich, Starawieś, 7 września 2006.

Dąbek D., Prawo sędziowskie w polskim prawie administracyjnym, Warszawa 2010.

Domańska M., Zasada autonomii proceduralnej państw czlonkowskich i jej ograniczenia wynikające z zasady efektywności, [w:] Stosowanie prawa Unii Europejskiej przez sady. Zasady orzecznictwo - piśmiennictwo, t. 2, red. A. Wróbel, Warszawa 2007.

Graczyk B., O niektórych zagadnieniach prejudycjalności w orzecznictwie administracyjnym, „Zeszyty Naukowe Uniwersytetu Łódzkiego. Prawo" 1965, nr 38.

Kaszubski M.P., Możliwość wznowienia postępowania administracyjnego z uwagi na późniejsze orzeczenie Trybunału Sprawiedliwości - w świetle sprawy Kühne, KPP 2004, nr 2.

Kmieciak Z., Wzruszalność ostatecznych (prawomocnych) rozstrzygnięć organów krajowych niezgodnych z unijnym porzadkiem prawnym i porzadkiem konwencyjnym, [w:] B. Baran et al., Europeizacja prawa administracyjnego, [w:] Kodeks postępowania administracyjnego. Komentarz, red. R. Hauser, M. Wierzbowski, Warszawa 2017.

Kodeks postępowania administracyjnego. Komentarz dla praktyków, red. L. Klat-Wertelecka, A. Mudrecki, Gdańsk 2012.

Koszowski M., Granice związania orzecznictwem Trybunału Sprawiedliwości Unii Europejskiej, [w:] Granice państwa jako granice jurysdykcji w Unii Europejskiej, red. S.M. Grochalski, Dąbrowa Górnicza 2012.

Majczak P., Podstawa prawna decyzji administracyjnej, „Ius Novum”2016, nr 4.

Półtorak N., Ochrona uprawnień wynikających z prawa Unii Europejskiej w postępowaniach krajowych, Warszawa 2010.

Przewodnik po prawie administracyjnym, red. W. Jakimowicz, Warszawa 2016.

Stosowanie prawa Unii Europejskiej przez sądy, red. A. Wróbel, Warszawa 2010.

System ochrony prawnej Unii Europejskiej, red. A. Wyrozumska, Warszawa 2010.

System Prawa Administracyjnego, t. 3, red. R. Hauser, Z. Niewiadomski, A. Wróbel, Warszawa 2014.

Woś T. (red. nauk.), Knysiak-Sudyka H., Romańska M., Prawo o postępowaniu przed sąami administracyjnymi. Komentarz, Warszawa 2016.

Wróbel A., Autonomia proceduralna, „Ruch Prawniczy, Ekonomiczny i Socjologiczny” 2005, z. 1. Wróbel A., Jaśkowska M., Kodeks postępowania administracyjnego. Komentarz, Warszawa 2016.

Zapała M., Stosowanie dyrektyw wspólnotowych przez organy administracyjne, PiP 2005, z. 11.

\section{Wykaz aktów prawnych}

Dyrektywa 2004/38/WE Parlamentu Europejskiego i Rady z dnia 29 kwietnia 2004 r. w sprawie prawa obywateli Unii i członków ich rodzin do swobodnego przemieszczania się i pobytu na terytorium Państw Członkowskich, zmieniająca rozporządzenie (EWG) nr 1612/68 i uchylająca dyrektywy 64/221/EWG, 68/360/EWG, 72/194/EWG, 73/148/EWG, 75/34/EWG, 75/35/ EWG, 90/364/EWG, 90/365/EWG i 93/96/EWG (Dz.U. UE. L. z 2004 r. Nr 158, s. 77).

Konstytucja Rzeczypospolitej Polskiej z dnia 2 kwietnia 1997 r. (Dz.U. Nr 78, poz. 483 ze zm.).

Projekt ustawy — Przepisy ogólne prawa administracyjnego.

Protokół Nr 3 w sprawie Statutu Trybunału Sprawiedliwości Unii Europejskiej (Dz.U. UE C 83/210). 
Traktat o Funkcjonowaniu Unii Europejskiej (Dz.U. UE C 83/01).

Ustawa z dnia 14 czerwca 1960 r. — Kodeks postępowania administracyjnego (tekst jedn. Dz.U. z 2016 r. poz. 23).

Ustawa z dnia 29 sierpnia 1997 r. — Ordynacja podatkowa (tekst jedn. Dz.U. z 2017 r. poz. 201).

Ustawa z dnia 30 sierpnia 2002 r. - Prawo o postępowaniu przed sądami administracyjnymi (tekst jedn. Dz.U. z 2016 r. poz. 718 ze zm.).

Ustawa z dnia 2 lipca 2004 r. o swobodzie działalności gospodarczej (tekst jedn. Dz.U. z 2016 r. poz. 1829 ze zm.).

Ustawa z dnia 14 lipca 2006 r. o wjeździe na terytorium Rzeczypospolitej Polskiej, pobycie oraz wyjeździe z tego terytorium obywateli państw członkowskich Unii Europejskiej i członków ich rodzin (tekst jedn. Dz.U. z 2017 r. poz. 900 ze zm.).

\section{Wykaz orzeczeń}

Postanowienie WSA w Gdańsku z dnia 28 czerwca 2005 r., II SA/Gd 188/05, LEX nr 180323.

Uchwała NSA w Warszawie z dnia 15 listopada 1999 r., OPK 24/99, LEX nr 40267.

Wyrok TS z dnia 22 czerwca 1989 r. w sprawie 103/88 FratelliCostanzoSpA przeciwko Comune di Milano, EU:C:1989:256.

Wyrok Trybunału z dnia 13 stycznia 2004 r. w sprawach połączonych C-6/90 i C-9/90 Andrea Francovich v. Republika Włoska, DanilaBonifaci i in. v. Republika Włoska, curia.europa.eu.

Wyrok Trybunału z dnia 13 stycznia 2004 r. w sprawie C-453/00 Kühne \&Heitz NV v. ProduktschapvoorPluimvee en Eieren, Legalis nr 67260.

Wyrok NSA z dnia 5 czerwca 1991 r., II SA 35/91, Legalis nr 36876.

Wyrok NSA w Warszawie z dnia 17 stycznia 1996 r., III SA 892/95, LEX nr 24009.

Wyrok NSA w Warszawie z dnia 21 kwietnia 2006 r., II OSK 770/05, LEX nr 211853.

Wyrok SN z dnia 6 stycznia 1999 r., III RN 101/98, LEX nr 37676.

Wyrok WSA w Warszawie z dnia 2 listopada 2005 r., VI SA/Wa 1515/05, LEX nr 214331. 